\title{
Recorregut de recerca de geològica i mineralògica per la comarca de l’Alta Ribagorça: des del Pont de Suert, a les Mines de Malpàs i a la Vall d'Adons
}

Josep Maria Mata-Perelló

Joaquim Sanz Balagué

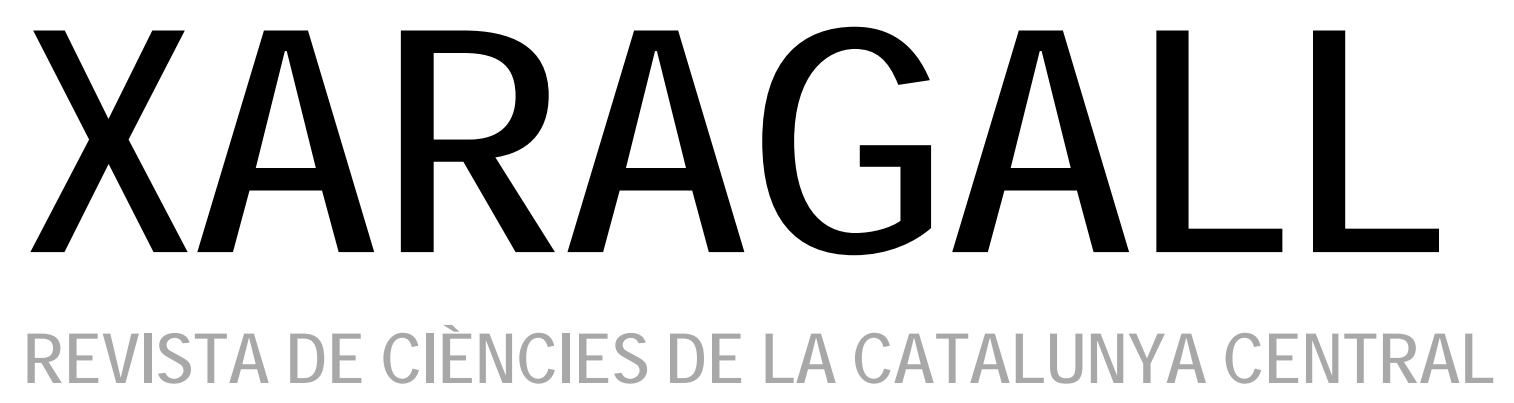

ก. 9

SETEMBRE 2015 


\title{
RECORREGUT DE RECERCA DE GEOLÒGICA I MINERALÒGICA PER LA COMARCA DE L'ALTA RIBAGORÇA: DES DEL PONT DE SUERT, A LES MINES DE MALPÀS I A LA VALL D’ADONS
}

\author{
Josep Maria Mata-Perelló \\ Museu de geologia Valentí Masachs, Escola Politècnica Superior d'Enginyeria de Manresa \\ (EPSEM), Universitat Politècnica de Catalunya · BarcelonaTech (UPC), 08272 Manresa, Spain
}

\section{Joaquim Sanz Balagué}

Departament d'Enginyeria Minera i Recursos Naturals (EMRN), Escola Politècnica Superior d'Enginyeria de Manresa (EPSEM), Universitat Politècnica de Catalunya . BarcelonaTech (UPC), 08272 Manresa, Spain

Paraules clau: Sistema Pirinenc, Patrimoni miner

\section{Resum}

Itinerari realitzat el 10 d'agost de 2014. En aquesta ocasió, la totalitat del present recorregut de l'itinerari discorrerà pel Sistema Pirinenc (i més concretament per la denominada Unitat de les Nogueres així com pel Mantell de Bóixols, en els darrers trams del recorregut de l'itinerari.

Així, el recorregut s'iniciarà al Pont de Suert, per anar després a les conegudes Mines de Malpàs, situades dintre de la Unitat de les Nogueres. Després, el recorregut es dirigirà cap el Sud, fins trobar la carretera $N-260$, per la qual s'anirà cap al Viu de Llevata. Aquest tram ja s' efectuarà dintre de la que podríem denominar com a zona d'interferència entre el Mantell de Bóixols i la Unitat de les Nogueres el qual ja no s'abandonarà fins a la fi del recorregut de I'itinerari. Posteriorment, es dirigirà cap a la Vall d'Adons, per on finalitzarà.

Per d'altra banda, el recorregut s'efectuarà íntegrament dintre de la comarca de l'Alta Ribagorça (i més concretament, sols pel terme del Pont de Suert). Així, començarà prop del propi poble del Pont de Suert, finalitzant prop del poble d'Adons, tot dintre de la mateixa comarca. 


\section{Objectius fonamentals}

Els objectius fonamentals que es pretenen aconseguir en aquest itinerari, es poden concretar en els següents aspectes generals:

1.- Observació dels materials paleozoics (del Devonià, Carbonífer i Permià) i dels mesozoics (del Triàsic) que formen part de la Unitat del Mantell de les Nogueres. Hi transitarem per ells entre el Pont de Suert i les Mines de Malpàs. Es tornarà a tallar, després en recórrer la Vall d’Adons, en una llenca que s'intrueix al Mantell de Bóixols.

2.- Observació i descripció dels materials secundaris (del Cretàcic), que formen part del Mantell de Bóixols (concretament de la Serra de Sant Gervasi), per on transitarem entre el pont del riu Peranera de la carretera N - 260 i la fi del recorregut, prop d'Adons, tret de la llenca de la que hem fet esment a l'apartat anterior.

3.- Observació del contacte entre les unitats geològiques acabades d'esmentar, i de les relacions entre elles. Generalment, es tracta d'un encavalcament de la Unitat del Mantell de les Nogueres, sobre el Mantell de Bóixols.

4.- Reconeixement de diverses mineralitzacions, que anirem trobant al llarg del recorregut. Aquestes, d'acord amb el sentit de la marxa, seran les següents:

4A) de les mineralitzacions calcosilicatades associades als afloraments d'ofites, les veurem al Pont de Suert i a Malpàs, dintre del Mantell de les Nogueres, entre els afloraments triàsics del Keuper.

4B) les mineralitzacions ferruginoses associades a alteracions de pirites, les veurem a Malpàs. Es troben associades a nivells carbonosos del Carbonífer del Mantell de les Nogueres

4C) si s'escau, de les mineralitzacions ferruginoses de rebliment de cavitats d'origen kàrstic. En tot cas, les veurem al Viu de Llevata, entre els materials cretàcics del Mantell de Bóixols.

5.- Estudi de les explotacions mineres associades amb les mineralitzacions anteriors; i també de les explotacions de roques carbonatades cretàciques, que trobarem prop de Adons, entre els materials del Mantell de Bóixols.

6. - Visió de l'impacte produït sobre el Medi Natural, com a conseqüència de les explotacions mineres anteriors. I, tanmateix de la restauració del mateix.

7.- Valorització del diferents indrets del Patrimoni Geològic i Miner que anem trobant al llarg del recorregut. Dintre del Patrimoni Miner, cal fer esment de tot el relacionat amb les Mines de Malpàs. 


\section{Antecedents}

Per la nostra banda, no tenim cap antecedent bibliogràfic relatiu a la totalitat del recorregut d'aquest itinerari. Hi ha, però, diversos antecedents parcials, relatius als darrers trams del recorregut. Entre aquests, farem esment dels següents: MATA-PERELLÓ $(1995,1996 \mathrm{a}, 1996 \mathrm{~b}$, 1998, 2000, 2001, 2002, 2013a, 2013b i 2013c). També cal fer esment del treball de MATAPEERELLÓ i MATA LLEONART (2000). Un altre antecedent molt recent és el de MATA PERELLÓ i SANZ BALAGÉ (2014).

Pel que fa a la descripció de les mineralitzacions situades a les comarques per les quals discorre l'itinerari, farem esment d'uns altres treballs nostres; concretament de MATAPERELLÓ (1990a, 1990b, 1991 i 1992) i de MATA-PERELLÓ i SANZ BALAGUÉ (1988 i 1993). En aquest sentit, també farem esment de l'important treball de MAESTRE (1845).

I, finalment, pel que fa a l'estructura geològica de la zona per la qual discorre l'itinerari, farem esment dels treballs generalistes de: GUIMERÀ et altri (1982) i de RIBA et altri (1976), tots dos referents al conjunt dels Països Catalans.

Tots aquests treballs i d'altres, figuren esmentats per ordre alfabètic a l'apartat dedicat a la BIBLIOGRAFIA ESMENTADA.

\section{Recorregut de l'itinerari}

Així, el recorregut de l'itinerari, s'iniciarà per les immediacions del poble del Pont de Suert, per on es farà la primera aturada, a la bora de la carretera de doble denominació, $\mathrm{N}-260$ / N - 230

Tot seguit, es continuarà per la carretera $N-260$, fins a trobar la Vall de Malpàs. A partir d'aquí, es segura per la carretera local $L-5212$, la qual remunta el riu Peranera., per tal d'anar cap a les Mines de Malpàs. En aquest indret ja s'efectuarà una nova aturada. Després, per la carretera local $L-5212$, s'anirà cap el pont del riu Peranera (o Noguera de Peranera), per la carretera nacional $\mathrm{N}-260$, on hi ha la cruïlla de carreteres. Poc abans d'arribar-hi, es farà una nova aturada.

Després, el recorregut continuarà per l'esmentada carretera N-260, ascendint ara el Pas de Llevata. En arribar a dalt, al Viu de Llevata, podrà fer-se una nova aturada, si es dona el cas. Després es continuarà, fins trobar el trencall d'Adons, que ens caldrà agafar, tot fent una nova fillola, amb la finalitat de fer una nova aturada. Poc despès d'arribar a les immediacions d'aquest poblet, finalitzarà el recorregut de l'itinerari. 


\section{Advertiments previs}

Com en altres recorreguts de RECERCA GEOLÒGICA I MINERALÒGICA ..., si es disposa del temps suficient, poden efectuar-se passant per totes les parades i filloles. En cas contrari, recomanem prescindir de les anomenades PARADES - CONDICIONALS.

També cal fer esment, de que alguns trams del recorregut es faran per camins en mal estat de conservació, per la qual cosa serà millor fer-los a peu. Aquest és el cas del camí d'aproximació cap a les Mines de Malpàs. Tanmateix és el cas d'aproximació al poble d’Adons.

En qualsevol cas, i com és natural, cal tenir sempre una cura molt especial de respecte a la natura, al llarg de tot el recorregut de l'itinerari.

\section{Descripció de l'itinerari}

Com de costum, estructurarem el recorregut de l'itinerari en una sèrie de PARADES, que tot seguit anirem veient. En cadascuna d'aquestes aturades farem un breu comentari (geològic 0 mineralògic, segons s'escaigui). Per d'altra banda, en cada cas indicarem, entre parèntesi, el full topogràfic on es troba l'aturada. Per fer-ho, utilitzarem els fulls editats per l'Instituto Geográfico y Catastral de España, publicats a l'escala de 1:50.000. En aquest cas, els fulls seran els següents: 213 (o del Pont de Suert), 214 (dit de Sort), 251 (o d'Areny) i 252 (també conegut com a full de Tremp) Així doncs, la relació de les aturades que composen el recorregut d'aquest itinerari, és la següent:

\subsection{Parada 1. ANTIGUES EXPLOTACIONS D'OFITES DEL PONT DE SUERT, (terme municipal del Pont de Suert, comarca de I’Alta Ribagorça). (full 213).}

Tot i que el recorregut el començarem a la cruilla de la carretera $\mathrm{N}-230$ / N -260 , amb la carretera $L-500$ (que baixa de la Vall de Boí), ens caldrà anar cap al Sud, cap al Pont de Suert. A menys de $1 \mathrm{Km}$ del poble i a uns 3 de l'inici del recorregut, ens caldrà fer una aturada.

En aquest recorregut, hem trobat inicialment els materials paleozoics del Devonià, que aquí formen part del Mantell de les Nogueres. Més avall haurem trobat afloraments dels materials mesozoics del Triàsic i del Cretàcic, tot i que predominaran ostensiblement els primers. Entre els del triàsic inicialment trobarem els gresos rogencs del Permotries i alguns trams carbonatats del Muschelkalk, Posteriorment els trams d'argiles i guixos del Keuper. Entre aquests materials també trobarem afloraments d'ofites. Tots aquests materials formen part de la Unitat del Mantell de la Zona de les Nogueres, on ens trobem ara situats, entre afloraments de les ofites triàsiques.

En aquest indret es fa força palès un interessat aflorament de les esmentades ofites del triàsic. En aquest indret han estat explotades, per tal de triturar-les i poder ésser emprades com a àrids per a la construcció. FOTOGRAFIA 1. 


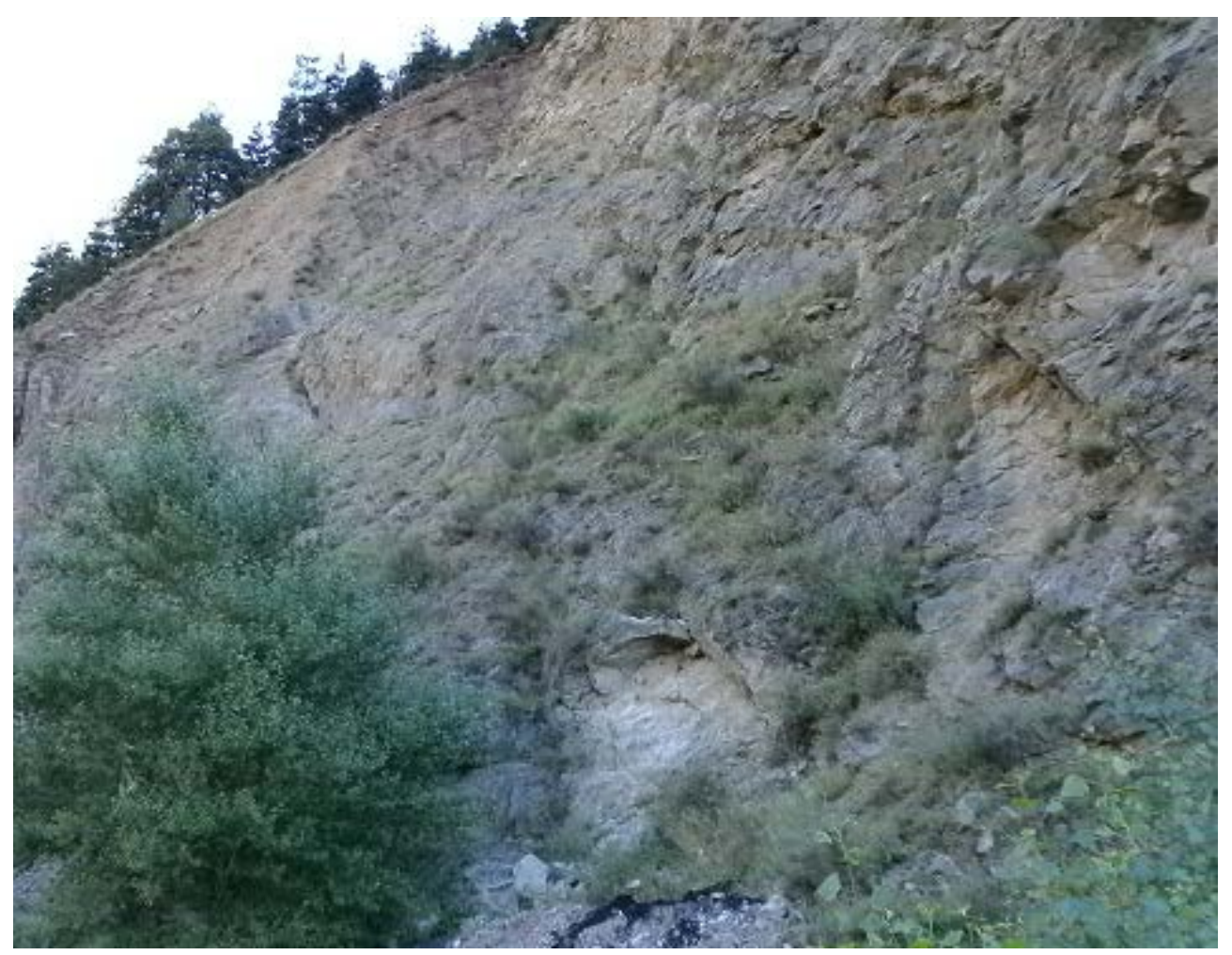

FOTOGRAFIA 1. PARADA 1

Explotació d'ofites del Pont de Suert

\subsection{Parada 2 - CONDICIONAL. PLANTA DE TRACTAMENT D'ÀRIDS DEL PONT DE SUERT, (terme municipal del Pont de Suert, comarca de l'Alta Ribagorça). (Full 213).}

Després de fer la parada anterior, cal acabar de baixar cap al Pont de Suert, travessant-lo. A la sortida de la població, es trobarà la cruillla d'on es separen les dues carreteres ara unides: la N230 i la N-260. Nosaltres seguirem aquesta darrera, però al poc d'agafar-la farem una nova parada, a uns $2 \mathrm{Km}$ de l'anterior.

En aquest breu recorregut, hem continuat trobant els materials esmentats a la parada anterior, els quals pertanyen a la Unitat del Mantell de la Zona de les Nogueres, en la qual continuem situats.

En aquest indret, hi ha una planta de tractament d'àrids. Abans hi havia una extracció, però a l'actualitat els àrids procedeixen d'altres indret, i aquí són triturats i classificats. 


\subsection{Parada 3. INICI DE LA CARRETERA LOCAL A MALPÀS, PONTET SOBRE EL RIU PERANERA, (antic terme de Malpàs i actualment del terme del Pont de Suert, comarca de I’Alta Ribagorça). (Full 213).}

Des de la parada anterior, cal continuar per la carretera N-260 (la qual es dirigeix cap a la Pobla de Segur). En arribar a la cruïlla amb la carretera de Malpàs (que ve per l'esquerra), farem una nova aturada, a uns $9 \mathrm{Km}$ de l'anterior. Aquesta aturada la farem, en realitat a uns $0,2 \mathrm{Km}$ de la cruïlla, després d'agafar la carretera local $L-5212$.

En aquest recorregut hem anat trobant els materials esmentats a les parades anteriors. Tot $\mathrm{i}$ així, en aquest tram haurem per entre el contacte entre la Unitat de Bóixols i la Unitat de les Nogueres, tot i que nosaltres haurem estat sempre dintre d'aquesta segona unitat esmentada. Així, el Mantell de Bóixols de la Unitat de Bóixols, ens quedarà al Sud d'on ara ens trobem situats. En els darrers dos-cents metres, hem trobat els materials del Triàsic Superior, del Keuper. Així, es fàcil veure trams d'argiles guixoses i afloraments d'ofites.

En aquest indret hi ha un aflorament dels materials del Keuper, amb nivells de guixos $\mathrm{i}$ d'argiles. I també amb la presència d'un important aflorament d'ofites. Precisament, en aquestes darreres es fa palesa l'existència de cristal-litzacions d'EPIDOT (d'aspecte microcristal.lí i d'un intens color verd) i de PREHNITA (d'aspecte globular, i molt ben cristal-litzada). També cal fer esment de la presència de petits cristalls de PIRITA, entre l'epidot. Ocasionalment, també s' han trobat mostres de CALCOPIRITA i de MALAQUITA.

Per d'altra banda, entre els nivells guixosos i argilosos, es troben petits cristallets de GIOBERTITA (fosca) i de QUARS (rogenc, en forma de Jacints de Compostel/là), juntament amb el GUIX i amb el CAOLÍ. FOTOGRAFIA 2

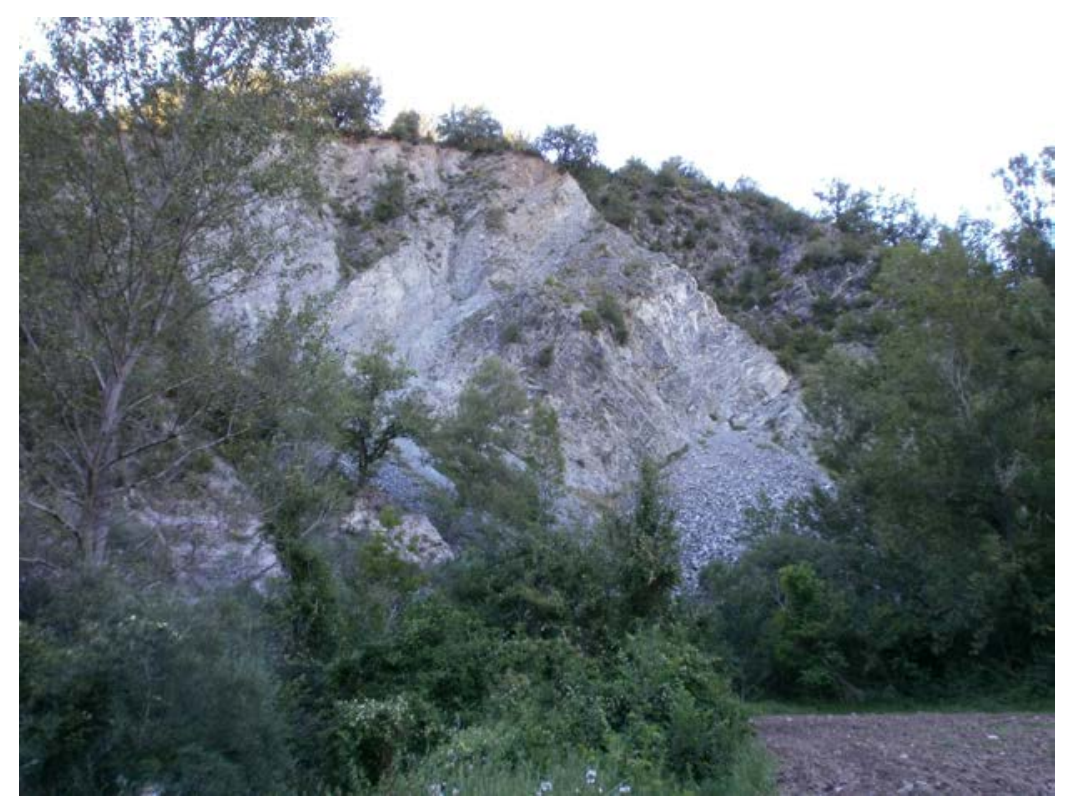

FOTOGRAFIA 2. PARADA 3

Aflorament de les ofites, al costat del riu Paranyera, prop de Malpàs. Agost del 2013 


\subsection{Parada 4. MINES DE MALPÀS. TREMUGES I FERROCARRILS, (Erill-Castell, antic terme de Malpàs, i actual del de Pont de Suert, comarca de l'Alta Ribagorça). (Full 213).}

Des de la parada anterior, cal fer una petita fillola, per tal d'anar cap a les antigues "Mines de Malpàs". Per anar-hi cal continuar per la carretera local que es dirigeix a Malpàs. Des d'aquest poble es continuarà cap a les esmentades mines (que va explotar l'empresa MIPSA), les quals es troben situades als peus de l'antic poble d'Erill-Castell, i enfront del de Peranera. Així farem un recorregut proper als $4 \mathrm{Km}$.

En aquest indret hi ha unes antigues explotacions carbonoses, a les quals s'aprofitaven uns importants nivells d'hulles incloses entre els materials del Carbonífer, que pertanyen a la Formació Malpàs. Aquests materials es troben situats al Mantell de les Nogueres.

Entre les hulles es troben diverses mineralitzacions eminentment ferruginoses, amb presència de: MARCASSITA. MELNIKOWITA (indicis), PIRITA (abundant, i sovint ben cristal.litzada), GOETHITA (limonítica), HEMATITES (poc abundant), SIDERITA (indicis), MELANTERITA i SIDEROTÍL. Amb els anteriors, també es troben altres minerals com: SOFRE (indicis), CALCITA, GUIX, CAOLINITA i QUARS, entre altres.

També cal fer esment de l'important patrimoni miner que hi ha en aquest indret: galeries, antigues instal-lacions dels carregadors, pontets dels ferrocarrils miners. Tot i el seu valor, a l'actualitat es troben en un avançat procés de degradació, fent-se força evident que cal una acció decidida per tal de salvaguardar aquest patrimoni. FOTOGRAFIES 2, 3 i 4.

Finalment, cal dir que les darreres explotacions, situades en aquest indret, es van tancar a finals dels anys seixanta, just després de la construcció de les grans presses situades al llarg del Noguera Ribagorçana. També, cal dir que aquestes mines eren les més importants de la denominada Conca Hullera de Malpàs, que s'estén per diverses localitats de l'Alta Ribagorça (Avellanos, Erill-Castell, Sas i Vilancos), i també del Pallars Jussà (a Erdo, Guiró i Oveix). 


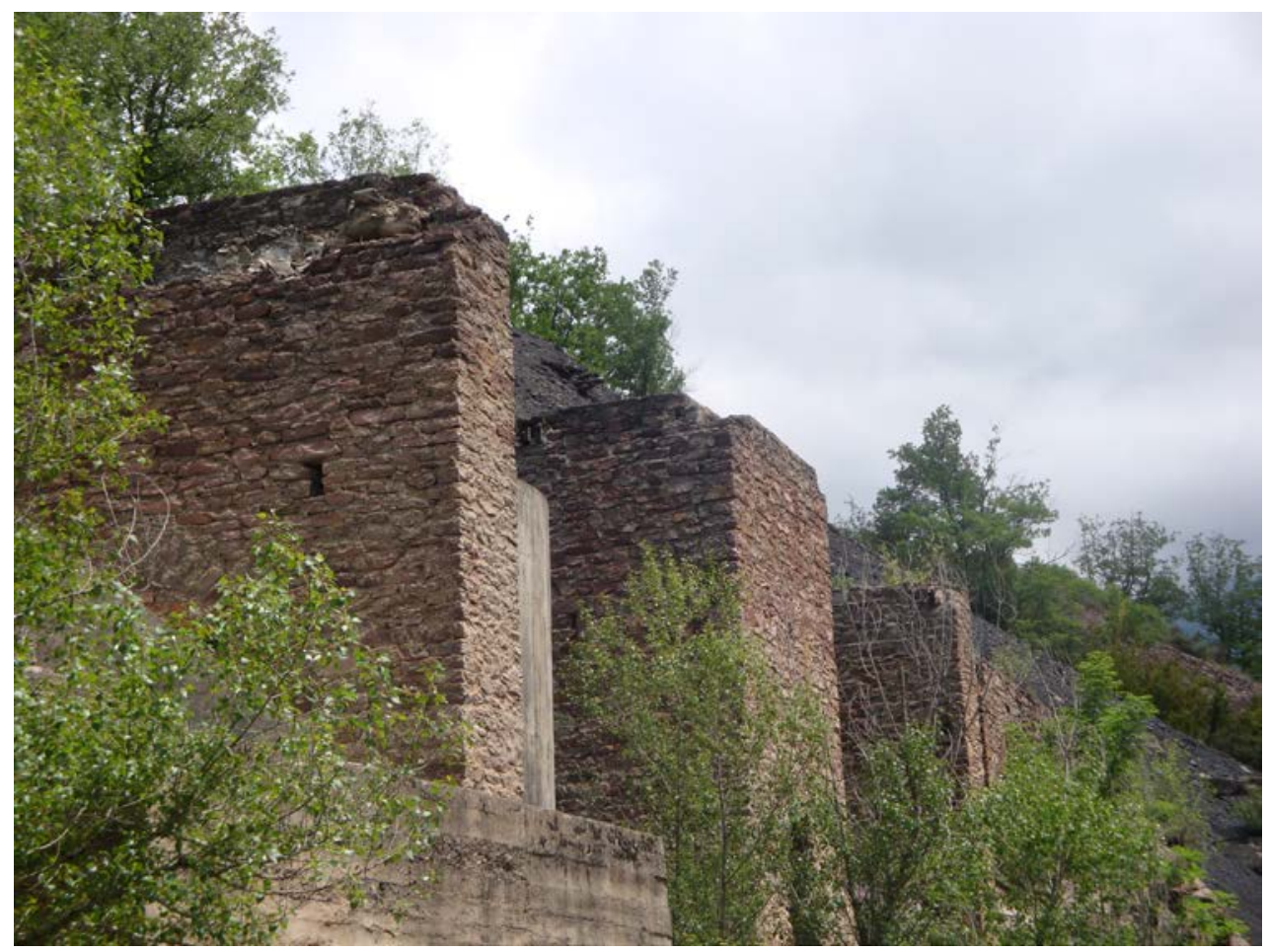

FOTOGRAFIA 2. PARADA 4

Un aspecte de les tremuges de les Mines de Malpàs

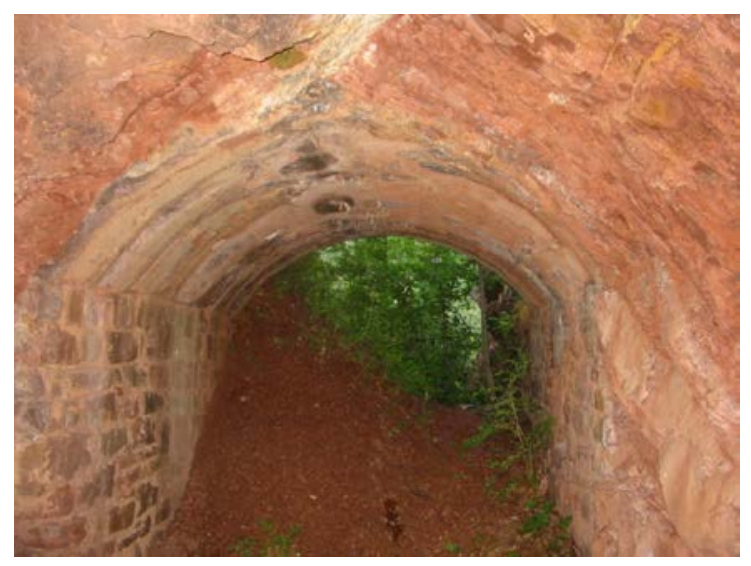

FOTOGRAFIA 3. PARADA 4

Un dels túnels dels ferrocarrils miners de les mines de Malpàs, Abril 2007

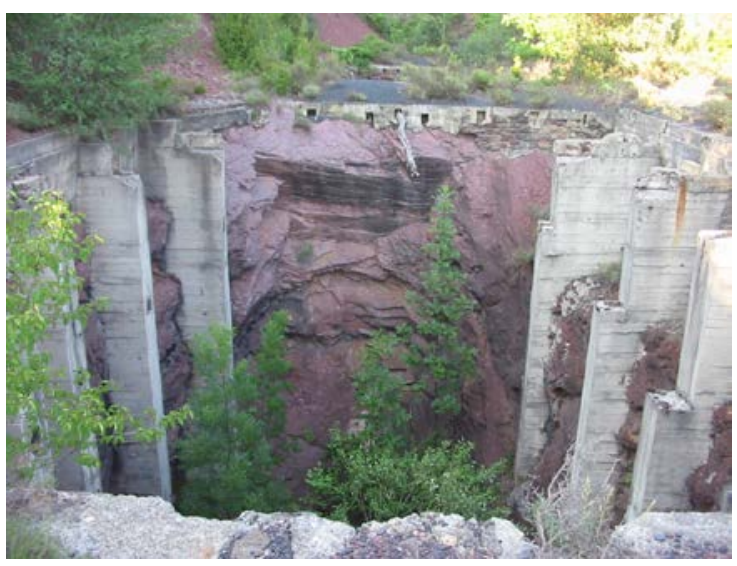

FOTOGRAFIA 4. PARADA 4

Base d'un dels ponts, per on circulava la línia fèrria, que anava de les mines cap a les tremuges. externes Abril 2007 
Tanmateix cal dir, que a l'altra banda del riu hi havia unes altres tremuges internes, just prop d'on sortia el telefèric que conduïa el carbó de Malpàs cap a Seniu i cap a la Cimentera de Xerallo, on s'utilitzava com a combustible. FOTOGRAFIES 5 i 6.

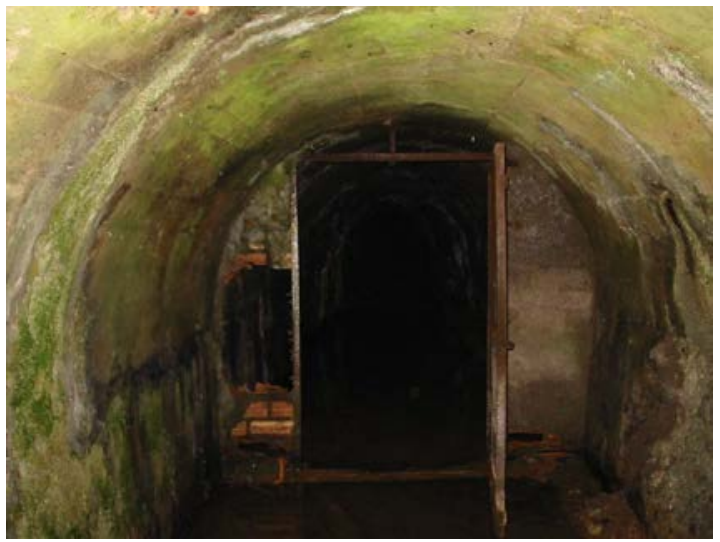

FOTOGRAFIA 5. PARADA 4

Restes de les tremuges internes de les Mines de Malpàs Juny 2009

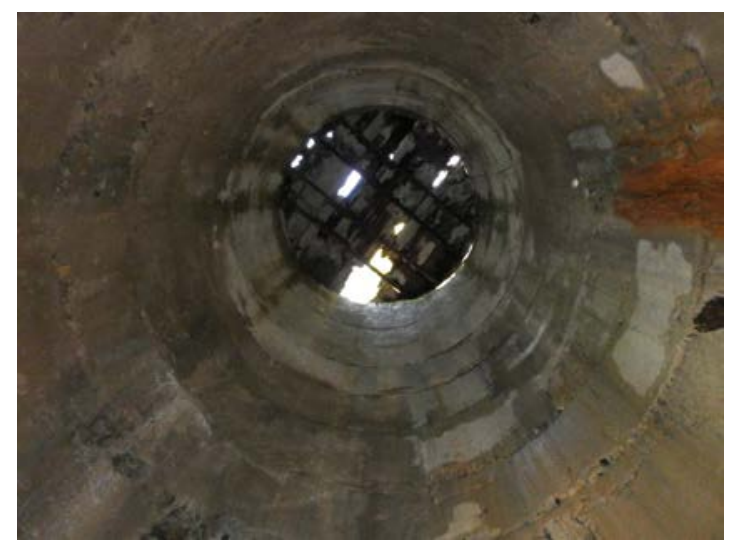

\section{FOTOGRAFIA 6. PARADA 4}

Tremuges internes de les Mines de Malpàs Juny 2009

Prop d'aquestes tremuges hi havia la casa d'administració de l'empresa minera i un interessant pont que creuava el riu Peranera. Per aquest pont s'iniciava la línia fèrria de la que hem parlat abans. FOTOGRAFIES 7 i 8.

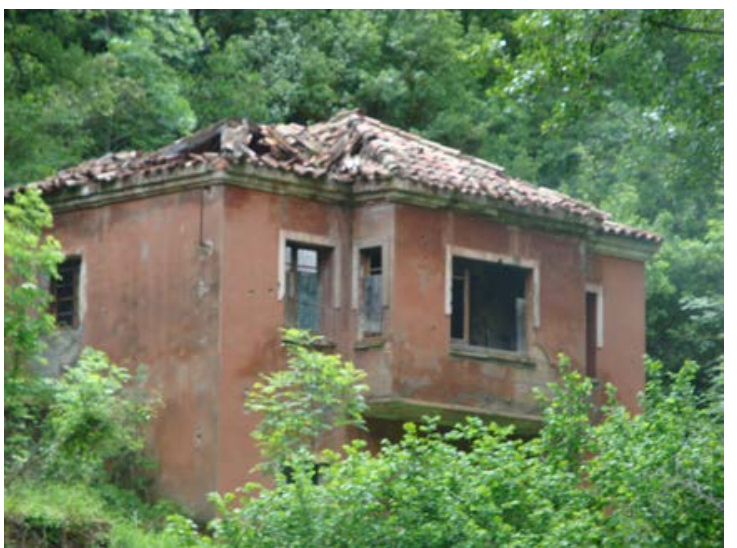

FOTOGRAFIA 7. PARADA 4

Un aspecte actual del edifici de les oficines de les Mines de Malpàs. Juliol 2002

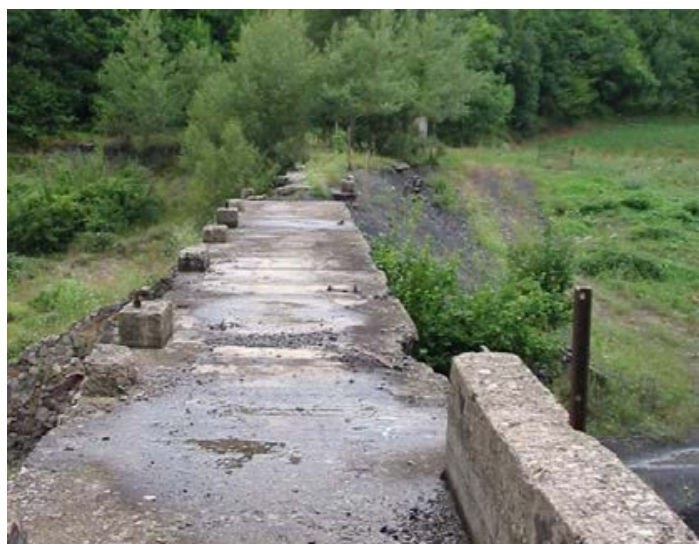

\section{FOTOGRAFIA 8. PARADA 4}

Un aspecte actual del pont per on s'iniciava la línia fèrria de les Mines de Malpàs. Juliol 2002 


\subsection{Parada 5. MINES DE MALPÀS, CARRETERA A PERANERA (Erill-Castell, antic terme de Malpàs, i actual del de Pont de Suert, comarca de l'Alta Ribagorça). (Full 213).}

Després de realitzar la parada anterior, cal fer un breu recorregut pel camí que condueix cap a Peranera i també cap el poble d'Erill Castell, tots dos aturonats sobre la vall del riu de Peranera (o Noguera de Peranera). Així, agafant aquest camí, menys de 0 ’ $3 \mathrm{Km}$ de la parada anterior, en podem realitzar una altra.

En aquest recorregut, hem anat trobant afloraments dels materials carbonosos del Permià i del Carbonífer. Efectivament, aquest aflorament dels materials del Carbonífer Superior y del Pèrmic, es troba al bell mig de la Unitat de les Nogueres. Sovint es veuen escombreres de les antigues explotacions. Cal dir que es tracta d'aforaments d'una gran bellesa, per la conjunció dels colors rojos i negres, enmig de la vegetació verda. FOTOGRAFIES 7 i 8

També cal dir que molt prop d'aquest indret hi ha un aflorament de roques volcàniques, les quals corresponen als Carbonífer..

Les darreres explotacions, situades en aquest indret, es van tancar a finals dels anys seixanta, just després de la construcció de les grans presses situades al llarg del Noguera Ribagorçana.

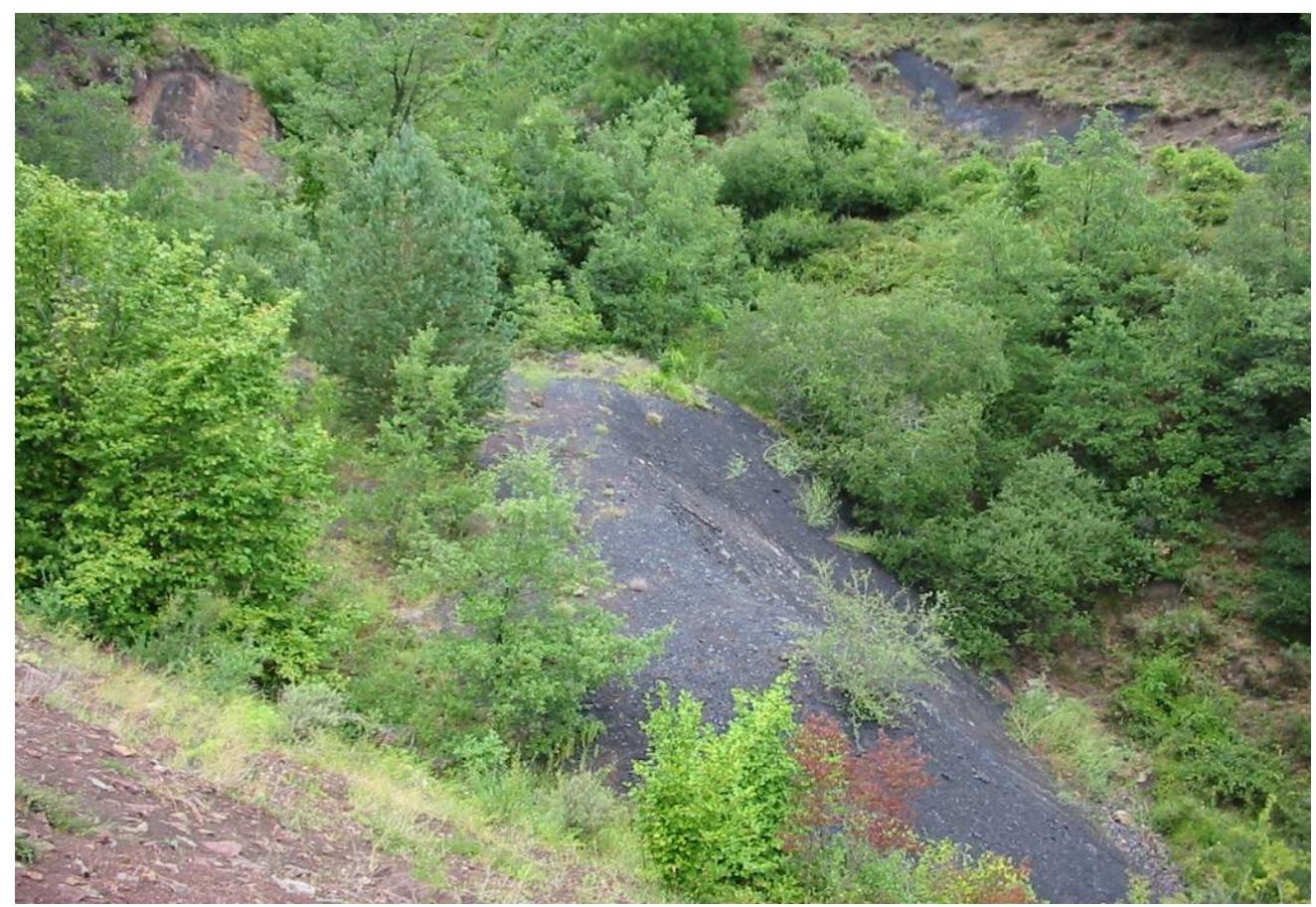

FOTOGRAFIA 8. PARADA 5

Una de les antigues escombreres. Abril 2000 


\subsection{Parada 6. EL PAS DE LLEVATA, (el Viu de Llevata, actualment pertany al terme municipal del Pont de Suert, abans era municipi propi, comarca de l'Alta Ribagorça). (Fulls 213 i 214).}

Des de la parada anterior, cal seguir ara per la carretera N-260, per la qual caldrà començar a pujar el Port del Pas de Llevata, arribant al poble del Viu de Llevata, on farem la present aturada, després de recórrer uns $7 \mathrm{Km}$ des de la parada anterior.

En aquest recorregut haurem entrat als contraforts septentrionals de la Serra de Sant Gervasi (dintre de la Mantell de Bóixols), trobant-nos freqüents afloraments dels materials mesozoics del Triàsic Superior (del Keuper, ja esmentats abans), així com del Cretàcic (amb nivells carbonatats). De fet, haurem transitat sempre per la zona d'interferència entre el Mantell de Bóixóls i la Unitat de les Nogueres.

Al Viu de Llevat es fa força palès un tram de calcàries, gairebé vertical, que destaca sobre el paisatge, i on s'ha situat la població, totalment arrecerada font els vents frescs del Nord.

Entre aquests nivells hi ha mineralitzacions ferruginoses de rebliment kàrstic, situades entre les calcàries. Els minerals presents són la GOETHITA (limonítica) i I'HEMATITES; així com la CALCITA (PARADA 4 - BIS).

\subsection{Parada 7 - CONDICIONAL. PEDRERES D'ADONS, (Adons, actualment pertany al terme del Pont de Suert, abans era del de Viu de Llevata, comarca de I’Alta Ribagorça). (Fulls 251 i 252).}

Després de fer l'aturada anterior, cal baixar cap a la vessant oriental del Pas de Llevata, seguint sempre la carretera nacional $\mathrm{N}-260$, fins a trobar la carretera local que es dirigeix cap al poble d'Adons, la qual ens caldrà agafar per tal de fer una fillola. Poc abans d'arribar-hi, farem una nova aturada, a menys de $4 \mathrm{~km}$ de l'anterior.

En aquest recorregut, hem continuat trobant afloraments de les roques carbonatades cretàciques, les quals formen part de la Serra de Sant Gervasi (integrant del Mantell de Bóixols i més concretament de la zona d'interferència que hem esmentat abans, on estem situats). Precisament, apareixen a l'indret de l'aturada, han estat explotades aquestes calcàries cretàciques, per tal d'ésser utilitzades com a àrids per a la construcció i per a les obres públiques. 


\subsection{Parada 8. COLLADA DE COMALLONGA, (Adons, actualment pertany al terme del Pont de Suert, abans era del de Viu de Llevata, comarca de l'Alta Ribagorça). (Fulls 251 i 252).}

A continuació de l'aturada anterior, cal continuar pel camí que ens ha dut fins aquí, deixant el trencall d'Adonsd. Després arribarem a la Beguda d'Adons, des d'on ens caldrà continuar cap a la Collada de Comallonga. Aquí farem la darrera aturada d'aquest itinerari, a uns $5 \mathrm{Km}$ de la parada anterior.

En aquest recorregut, hem estat circulant inicialment pel Mantell de Bóixols. Tot i això, haurem estat dintre de la que hem denominat zona d'interferència entre el Mantell de Bóixols (amb afloraments del Cretàcic) i el Mantell de Les Nogueres (per on afloren ara els materials del Keuper i del Devonià).

Tot i així, en arribar a l'indret de la present aturada, veurem l'encavalcament del Mantell de la Unitat de les Nogueres (en concret de la llenca que acabem de travessar) sobre els materials cretàcics de la Serra de Sant Gervasi, la qual forma part del Mantell de Bóixols, per on hem estat circulant abans.

Per d'altra banda, des d'aquest indret es pot gaudir d'una bona observació de l'Anticlinal de la Serra de Sant Gervasi. Tot i que no és tan bona com la que es pot veure des del proper poblet de Curruncui. FOTOGRAFIA 9.

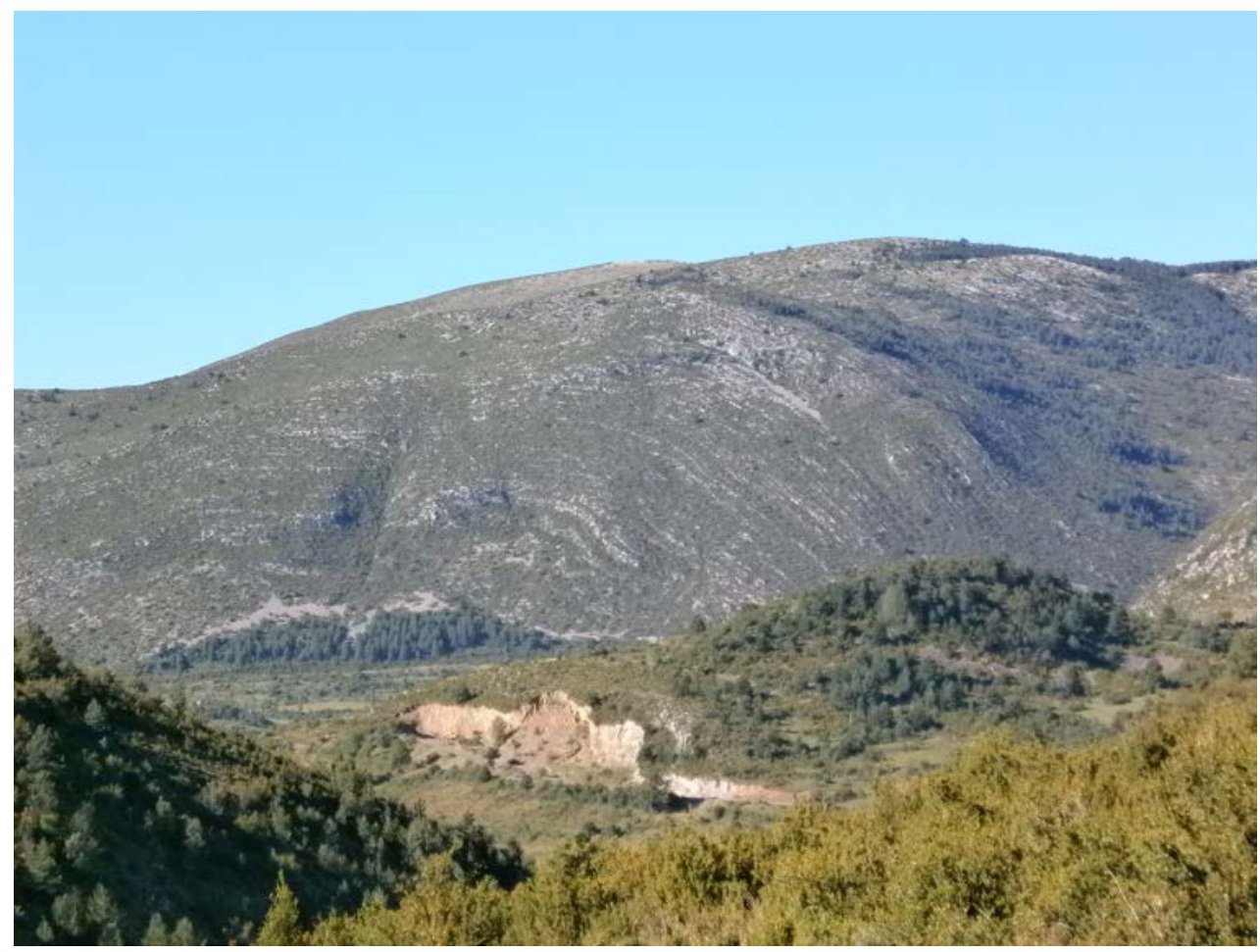

FOTOGRAFIA 9. PARADA 8

Anticlinal de la Serra de Sant Gervasi. En primer terme la graveres de la PARADA 7.

Agost del 2013 
En aquest indret finalitza el recorregut de l'itinerari

\section{Bibliografia}

GUIMERÀ, J. et altri (1992).- Geologia (II). Història Natural dels Països Catalans. Vol. 2, 547 pag. Enciclopèdia Catalana, S.A. Barcelona

MAESTRE, A. (1845).- Descripción geognòstica del Distrito Minero de Cataluña y Aragón. Anales de Minas, tomo iil. Madrid.

MATA-PERELLÓ,J.M. (1991).- Els Minerals de Catalunya. Arxius de la Secció de Ciències de I'Institut d'Estudis Catalans, vol.47, 545 pag. Barcelona

MATA-PERELLÓ, J.M. (1995).- Itinerari geològic i mineralògic per l'Alta Ribagorça: des de Malpàs a Senet. Inèdit. 8 pàgines. Manresa

MATA-PERELLÓ, J.M. (1996a).- Selecció d'itineraris geològicos i mineralògics per les terres de Lleida. Pub. Museu de Geologia "Valentí Masachs", 72 pàgines. Manresa

MATA-PERELLÓ, J.M. (1996b).- Itinerari geològico-mineralògic per l'Alta Ribagorça i per la Val d'Aran: des de Malpàs a Vielha, i des del Pont de Suert a Cerler. Inèdit, 14 pàgines. Manresa

MATA-PERELLÓ, J.M. (1998).- Itinerari geològic i mineralògic per I'Alta Ribagorça i per la Vall de Benasc (Ball de Benás): des de Malpas a Senet, i des de Vilaller a Castillo de Sos. Inèdit, 12 pàgines. Manresa

MATA-PERELLÓ, J. M. (2000).- Recorregut de recerca geològica i mineralògica per les comarques de I'Alta Ribagorça i de la Val d'Aran: des de Malpàs al Túnel de Vielha, per Pont de Suert. Terra Endins, n 18, 10 pàg. Manresa

MATA-PERELLÓ, J.M. (2001).- Recorregut de recerca geològica i mineralògica per les comarques de I'Alta Ribagorça i de la Val d'Aran: des de Malpàs al túnel de Vielha per Pont de Suert. Terra Endins, sèrie $B, n^{\circ} 18,15$ pag. Manresa

MATA-PERELLÓ, J. M. (2002).- Recorregut de recerca de geològica i mineralògica per les comarques de I'Alta Ribagorça i del Pallars Jussà: des de la Pressa de Colomers a Malpàs i a la Vall de Manyanet. Inèdit. 12 pàgines. Manresa

MATA-PERELLÓ, J. M. (2013a).- Recorregut de recerca geològica i mineralògica per les comarques del Pallars Jussà i de I'Alta Ribagorça: des de la Mola d'Amunt a Sentís, Sas, Erta, Paranyera i a Malpàs. Inèdit. 12 pàgines. Manresa

MATA-PERELLÓ, J. M. (2013b).- Recorregut de recerca geològica i mineralògica per les comarques de la Val d'Aran i de l"Alta Ribagorça: des del Túnel de Vielha a Senet, Aneto, Llauset i a Malpàs. Inèdit. 16 pàgines. Manresa

MATA-PERELLÓ, J. M. (2013c).- Recorregut de recerca de geològica i mineralògica per la comarca de I'Alta Ribagorça: des de les Mines de Malpàs a Adons i a Corroncui.

Inèdit. 10 pàgines. Manresa

MATA-PERELLÓ, J.M. i MATA LLEONART, R. (2000).- Recorregut de recerca geològica i mineralògica per les comarques del Pallars Jussà i de I'Alta Ribagorça: des de Senterada al Pont de Malpàs, Terra Endins, nº 17, 7 pàg. Manresa 
MATA-PERELLÓ, J.M. i SANZ BALAGUÉ, J. (1988).- Guia d'identificació de minerals. Edit Parcir, 205 pàg. Manresa

MATA-PERELLÓ, J.M. i SANZ BALAGUÉ, J. (1993).- Guia de Identificación de Minerales, adaptada fundamentalmente a la Península Ibérica. Edic. Parcir, 243 pàgines Manresa

MATA-PERELLÓ, J.M. i SANZ BALAGUÉ, J. (2014).- Recorregut de recerca de geològica i mineralògica per les comarques de I'Alta Ribagorça i del Pallars Jussà: des de les Bordes a Pont de Suert, a les Mines de Malpàs, Adons, Corroncui i a Erinyà. Inèdit. 20 pàgines. Manresa

RIBA ARDERIU, O. et altri (1976).- Geografia Física dels Països Catalans, Edit. Ketres. Barcelona 